\title{
Discovery of the serum biomarker proteins in severe preeclampsia by proteomic analysis
}

\author{
Jisook Park ${ }^{1 *}$, Dong Hyun Cha ${ }^{2 *}$, Soo Jae Lee ${ }^{1}$, \\ Young Nam $\mathrm{Kim}^{3}$, Young Hwan $\mathrm{Kim}^{4}$ \\ and Kwang Pyo Kim ${ }^{1,5}$ \\ ${ }^{1}$ Department of Molecular Biotechnology \\ Institute of Biomedical Science and Technology \\ Konkuk University \\ Seoul 143-701, Korea \\ ${ }^{2}$ Department of Obstetrics and Gynecology \\ Kangnam CHA Hospital \\ CHA University \\ Seoul 135-080, Korea \\ ${ }^{3}$ Department of Obstetrics and Gynecology \\ Inje University \\ Pusan Paik Hospital \\ Busan 614-735, Korea \\ ${ }^{4}$ Division of Mass Spectrometry Research \\ Korea Basic Science Institute \\ Ochang 363-883, Korea \\ ${ }^{5}$ Corresponding author: Tel, 82-2-458-7682; \\ Fax, 82-2-452-5558; E-mail, kpkim@konkuk.ac.kr \\ *These authors contributed equally to this work. \\ DOI 10.3858/emm.2011.43.7.047
}

Accepted 31 May 2011

Available Online 3 June 2011

Abbreviations: AHSG, $\alpha 2$-HS-glycoprotein; AMBP, $\alpha 1$-microglobulin/ bikunin; CID, collision-induced dissociation; ESI, electrospary ionization; FDR, false discovery rate; IGFBP-ALS, insulin like growth factor binding protein, acid labile subunit; MS, mass spectrometry; $\mathrm{PE}$, preeclampsia; RBP4, retinol binding protein 4; SRM, selective reaction monitoring

\footnotetext{
Abstract

Preeclapsia (PE) is a severe disorder that occurs during pregnancy, leading to maternal and fetal morbidity and mortality. PE affects about 3-8\% of all pregnancies. In this study, we conducted liquid chromatographymass spectrometry/mass spectrometry (LC-MS/MS) to analyze serum samples depleted of the six most abundant proteins from normal and PE-affected pregnancies to profile serum proteins. A total of 237 proteins were confidently identified with $<1 \%$ false discovery rate from the two groups of duplicate analysis. The expression levels of those identified proteins were compared semiquantitatively by spectral counting. To
}

further validate the candidate proteins with a quantitative mass spectrometric method, selective reaction monitoring (SRM) and enzyme linked immune assay (ELISA) of serum samples collected from pregnant women with severe $P E(n=8)$ or normal pregnant women $(n=5)$ was conducted. $\alpha 2-$ HS-glycoprotein (AHSG), retinol binding protein 4 (RBP4) and $\alpha$-1-microglobulin/bikunin (AMBP) and Insulin like growth factor binding protein, acid labile subunit (IGFBP-ALS) were confirmed to be differentially expressed in PE using SRM $(P<0.05)$. Among these proteins, AHSG was verified by ELISA and showed a statistically significant increase in PE samples when compared to controls.

Keywords: $\alpha 2 \mathrm{HS}$-glycoprotein; biomarkers; pre-eclampsia; spectrometry, mass, electrospray ionization; proteomics; serum

\section{Introduction}

Preeclampsia (PE) is a disorder defined by new-onset hypertension and proteinuria after 20 weeks of gestation that can present as late as 4-6 weeks postpartum. PE affects $3-8 \%$ of all pregnancies and is a major cause of maternal morbidity and mortality (Noris et al., 2005). However, the underlying pathogenesis of preeclampsia remains unknown, and the development of adequate biomarkers for its diagnosis and prognosis have not yet been developed (Jauniaux et al., 2006). PE is generally characterized as follows: 1 ) during the early period of pregnancy, the placenta releases several growth factors into the maternal circulation, producing excessive systemic inflammation in response to ischemic hypoxia and oxidative stress (Borzychowski et al., 2006). 2), the generalized endothelial dysfunction leads to maternal characteristic symptoms of preeclampsia such as hypertension and proteinuria during the late period of pregnancy (Taylor, 1997). Although PE has been studied for a long time, there are currently no reliable biomarkers to predict PE during early pregnancy.

Recently, many groups have been giving special attention to serum proteins related to obesity, low grade inflammation and hypertriacylglycerolemia, which are common symptoms in PE (Smets et al., 2006). Various serum proteins are considered to 
contribute to the symptoms of PE, such as placental growth factor (PIGF), vascular endothelial growth factor (VEGF), soluble vascular endothelial growth factor receptor-1 (sVEGFR-1), soluble fms-like tyrosine kinase-1(sFlt-1), placental protein 13 (PP13), pregnancy-associated plasma protein A (PAPP-A), human chorionic gonadotrophin (HCG), soluble endoglin (sEng), alpha fetoprotein (AFP), insulin like growth factor-1 and IGF-binding protein-1 (IGFBP-1) (Muller et al., 1996; Bersinger and Odegard, 2004; Audibert et al., 2005; Venkatesha et al., 2006; Baumann et al., 2007; Spencer et al., 2008; Teixeira et al., 2008).

Various studies have shown that the expression levels of these proteins increase or decrease according to the disorder and its degree in PE (Baumann et al., 2007). However, it is not certain if these proteins would serve as new marker proteins for the diagnosis of PE in clinical practice. Because of these proteins relatively low specificities for the disease, further development is required for its application of clinical use.

To enable commercial use, it is necessary overcome challenges such as validation, reproducibility and specificity against novel marker proteins. Additionally, analysis of biological fluid that has high complexity and a dynamic range requires elaborate pre-preparation and more sensitive techniques (Hu et al., 2006).

For these reasons, in this study, we systematically compared the maternal serum proteome in women with PE and normal pregnancy using LC-MS based proteomic technologies following depletion of highly abundant serum proteins, such as albumin, immunoglobulin, and transferring, etc. A total of 237 serum proteins were confidently identified from serum samples of women with PE and normal from $1 \%$ false discovery rate searches (FDR). Among them, 97 proteins having multiple unique peptides were retained for group comparison. The differential expression levels of the selected proteins were validated using a quantitative mass spectrometric method, selective reaction monitoring (SRM) (Ji et al., 2003) and enzyme linked immune assay (ELISA).

\section{Results}

Mining of novel biomarkers from human biological fluids poses many challenges that must be overcome through a proteomics approach, such as the wide dynamic range in abundance and complexity of protein components. Accordingly, various attempts have been made to discover new biomarker proteins with clinical values (Whiteaker et al., 2007). Herein, we endeavored to identify new marker
Table 1. Patient's clinical characteristics

\begin{tabular}{lcc}
\hline $\begin{array}{c}\text { Clinical } \\
\text { parameter }\end{array}$ & $\begin{array}{c}\text { Pre-eclampsia } \\
(\mathrm{n}=8)\end{array}$ & $\begin{array}{c}\text { Normal } \\
\text { outcome }(\mathrm{n}=5)\end{array}$ \\
\hline Maternal age (yrs) & 30.75 & 32.4 \\
& $(25-33)$ & $(28-38)$ \\
Gestational age (wks ) & 31.375 & 38.6 \\
& $(27-39)$ & $(37-41)$ \\
Birth weight (kg) & 1.5025 & 3.184 \\
& $(0.78-3.16)$ & $(2.71-3.91)$ \\
Cesarean section (\%) & 8 & 5 \\
& $(100 \%)$ & $(100 \%)$ \\
\hline
\end{tabular}

A

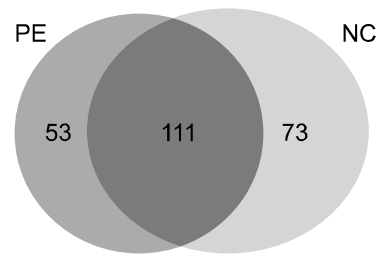

B

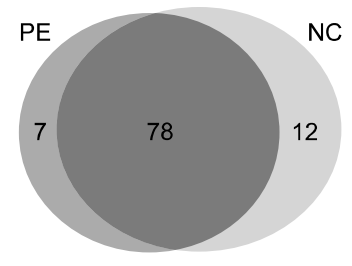

Figure 1. Venn diagram of Identified proteins from both groups; (A) shows proteins identified with single peptide hit. Total of 111 proteins shared between the PE and NC group. (B) represents the proteins that have multiple unique peptides. Seventy eight proteins were shared in both group.

proteins for PE using data dependent LC-MS/MS for both identification and semi quantification. The expression level of the differentially expressed proteins was further validated by the mass spectrometric quantification method, SRM, and ELISA.

We analyzed individual serum samples from five patients per group in duplicate by LC-MS/MS to identify the serum proteins (Table 1 ). In this analysis, the collected serum samples were treated using a multiple affinity removal column (MARS) containing six antibodies against albumin, $\lg G, \lg A$, transferrin, haptoglobin, and alpha-1-antitrypsin (Ryu et al., 2010). After high abundant protein depletion, the serum samples were digested using a sequence grade trypsin for LC-MS/MS analysis to compare the serum proteomes from women with $P E$ and those from women undergoing normal pregnancy.

The resulting MS/MS spectra were searched with SEQUEST algorithms using a composite target decoy database strategy to evaluate the confidence of peptide (Ballif et al., 2005). We acquired 5984 and $5744 \mathrm{MS} / \mathrm{MS}$ spectra from the PE group $(n=5)$ and normal group $(n=5)$, respectively. A total of 237 proteins with $1 \%$ FDR were assigned from those spectra (Figure 1A). We limited the positive protein set to proteins identified by multiple peptides. Among them, 97 proteins were matched with $2 \leq$ unique peptides (Figure 1B) (Table 2), and 
Table 2. Total identified proteins; A total of 237 proteins were acquired from both groups with 1\% FDR, with 97 of these proteins having multiple peptides. Each group had 85 and 90 serum proteins that were identified with multiple peptides

\begin{tabular}{lccc}
\hline Group & $\begin{array}{c}\text { Total number of } \\
\text { IDed proteins } \\
\text { (Multiple } \\
\text { peptide Hit) }\end{array}$ & $\begin{array}{c}\text { Total number of } \\
\text { IDed proteins } \\
\text { (Single } \\
\text { peptide Hit) }\end{array}$ & $\begin{array}{c}\text { Total number } \\
\text { of spectra }\end{array}$ \\
\hline PE & 85 & 165 & 5984 \\
Normal & 90 & 185 & 5744 \\
\hline
\end{tabular}

these were subjected to further annotation and validation. Consequently we identified 85 proteins and 90 proteins form serum samples of PE and serum samples of normal pregnancies, respectively. Among the 85 proteins identified in the PE groups, 49 proteins were identified in all five patients. Furthermore, 49 proteins were identified in all five patients among the 90 proteins identified in the normal group.

Among the 97 confidently identified proteins, 78 were identified in both groups. To screen potential

Table 3. The fold changes in protein levels by spectral counts, which is one of the relative quantitative methods used in proteomics; All proteins identified are listed based on their expression alteration and 62 proteins are differentially expressed with a 1.2 fold change cutoff. Among them, 27 proteins are up regulated, whereas 35 proteins are down regulated

\begin{tabular}{|c|c|c|c|c|c|c|c|}
\hline \multicolumn{2}{|c|}{ Up-regulated Proteins in Preeclampsia patients } & \multicolumn{2}{|c|}{ Unique peptide number } & \multicolumn{2}{|c|}{ Spectral Counts } & \multicolumn{2}{|c|}{$\%$ Ratio } \\
\hline Description & Accession $^{a}$ & $\mathrm{NCgr}^{\mathrm{b}}$ & $\mathrm{PEgr}^{\mathrm{c}}$ & NCgr & PEgr & NC/PE & $\mathrm{PE} / \mathrm{NC}$ \\
\hline Alpha 1 globin & 4504347 & 0 & 4 & & 42 & 0 & only PE \\
\hline $\begin{array}{l}\text { Alpha-1-microglobulin/ } \\
\text { bikunin precursor }\end{array}$ & 4502067 & 4 & 6 & 27 & 45 & 60 & 167 \\
\hline Alpha-2-HS-glycoprotein & 156523970 & 12 & 14 & 194 & 240 & 81 & 124 \\
\hline Apolipoprotein A-II preproprotein & 4502149 & 6 & 6 & 82 & 117 & 70 & 143 \\
\hline Apolipoprotein C-II precursor & 32130518 & 2 & 2 & 14 & 17 & 82 & 121 \\
\hline Beta globin & 4504349 & 0 & 7 & & 45 & 0 & only PE \\
\hline Clusterin isoform 1 & 42716297 & 4 & 3 & 18 & 22 & 82 & 122 \\
\hline $\begin{array}{l}\text { Complement component } 1 \text {, } \\
\text { q subcomponent, gamma polypeptide }\end{array}$ & 56786155 & 2 & 2 & 4 & 7 & 57 & 175 \\
\hline Complement component 6 precursor & 4559406 & 6 & 4 & 11 & 15 & 73 & 136 \\
\hline $\begin{array}{l}\text { Complement component } 8 \\
\text { gamma polypeptide }\end{array}$ & 4557393 & 3 & 3 & 4 & 10 & 40 & 250 \\
\hline Complement factor H-related 3 & 54792787 & 2 & 3 & 5 & 7 & 71 & 140 \\
\hline Delta globin & 4504351 & 0 & 3 & & 20 & 0 & only PE \\
\hline Fibronectin 1 isoform 2 preproprotein & 47132551 & 21 & 24 & 50 & 78 & 64 & 156 \\
\hline Gelsolin isoform a precursor & 4504165 & 5 & 6 & 14 & 18 & 78 & 129 \\
\hline $\begin{array}{l}\text { Insulin-like growth factor binding } \\
\text { protein, acid labile subunit }\end{array}$ & 4826772 & 2 & 4 & 4 & 6 & 67 & 150 \\
\hline $\begin{array}{l}\text { Inter-alpha (globulin) inhibitor H3 } \\
\text { preproprotein }\end{array}$ & 133925809 & 3 & 2 & 3 & 4 & 75 & 133 \\
\hline $\begin{array}{l}\text { Inter-alpha globulin inhibitor } \mathrm{H} 2 \\
\text { polypeptide }\end{array}$ & 70778918 & 16 & 12 & 69 & 101 & 68 & 146 \\
\hline Lumican precursor & 4505047 & 5 & 3 & 8 & 12 & 67 & 150 \\
\hline Paraoxonase 1 & 19923106 & 4 & 6 & 18 & 22 & 82 & 122 \\
\hline $\begin{array}{l}\text { Peptidoglycan recognition protein } \\
2 \text { precursor }\end{array}$ & 156616294 & 5 & 3 & 5 & 10 & 50 & 200 \\
\hline $\begin{array}{l}\text { Pregnancy specific beta- } \\
\text { 1-glycoprotein } 9\end{array}$ & 156616284 & 2 & 3 & 4 & 6 & 67 & 150 \\
\hline Proteoglycan 2 preproprotein & 46276889 & 0 & 2 & & 3 & 0 & only PE \\
\hline $\begin{array}{l}\text { Serine (or cysteine) proteinase inhibitor, } \\
\text { Clade A (alpha- } 1 \text { antiproteinase, } \\
\text { Antitrypsin), member } 1\end{array}$ & 50363221 & 0 & 7 & & 12 & 0 & only PE \\
\hline $\begin{array}{l}\text { Serpin peptidase inhibitor, clade A, } \\
\text { member } 3 \text { precursor }\end{array}$ & 50659080 & 5 & 5 & 20 & 35 & 57 & 175 \\
\hline Serum amyloid $\mathrm{P}$ component precursor & 4502133 & 2 & 3 & 4 & 10 & 40 & 250 \\
\hline Transthyretin & 4507725 & 8 & 10 & 23 & 60 & 38 & 261 \\
\hline Von Willebrand factor preproprotein & 89191868 & 0 & 2 & 1 & 4 & 25 & 400 \\
\hline
\end{tabular}


Table 3. Continued

\begin{tabular}{|c|c|c|c|c|c|c|c|}
\hline \multicolumn{2}{|c|}{ Down-regulated Proteins in Preeclampsia patients } & \multicolumn{2}{|c|}{ Unique peptide number } & \multicolumn{2}{|c|}{ Spectral Counts } & \multicolumn{2}{|c|}{$\%$ Ratio } \\
\hline Description & Accession $^{\mathrm{a}}$ & $\mathrm{NCgr}^{\mathrm{b}}$ & $\mathrm{PEgr}^{\mathrm{C}}$ & NCgr & PEgr & $\mathrm{NC/PE}$ & $\mathrm{PE} / \mathrm{NC}$ \\
\hline Afamin precursor & 4501987 & 11 & 14 & 62 & 51 & 122 & 82 \\
\hline Albumin precursor & 4502027 & 38 & 15 & 120 & 27 & 444 & 23 \\
\hline Alpha-2-plasmin inhibitor & 115583663 & 2 & 2 & 6 & 4 & 150 & 67 \\
\hline Apolipoprotein A-IV precursor & 71773110 & 10 & 8 & 53 & 30 & 177 & 57 \\
\hline Apolipoprotein D precursor & 4502163 & 4 & 2 & 7 & 5 & 140 & 71 \\
\hline Apolipoprotein M & 22091452 & 2 & 0 & 2 & 1 & 200 & 50 \\
\hline Coagulation factor XII precursor & 145275213 & 5 & 4 & 15 & 8 & 188 & 53 \\
\hline $\begin{array}{l}\text { Complement component } 4 \text { binding } \\
\text { protein, alpha chain precursor }\end{array}$ & 4502503 & 4 & 0 & 9 & 1 & 900 & 11 \\
\hline $\begin{array}{l}\text { Complement component } 4 \mathrm{~A} \\
\text { preproprotein }\end{array}$ & 67190748 & 22 & 17 & 86 & 58 & 148 & 67 \\
\hline $\begin{array}{l}\text { Complement component 4B } \\
\text { preproprotein }\end{array}$ & 158037400 & 21 & 11 & 79 & 34 & 232 & 43 \\
\hline Complement component 7 precursor & 45580688 & 6 & 0 & 7 & 1 & 700 & 14 \\
\hline $\begin{array}{l}\text { Complement component } 8 \\
\text { alpha polypeptide precursor }\end{array}$ & 4557389 & 3 & 2 & 9 & 4 & 225 & 44 \\
\hline $\begin{array}{l}\text { Complement component } 8 \text {, } \\
\text { beta polypeptide preproprotein }\end{array}$ & 4557391 & 2 & 0 & 2 & 1 & 200 & 50 \\
\hline Complement component 9 & 4502511 & 8 & 3 & 12 & 8 & 150 & 67 \\
\hline $\begin{array}{l}\text { Complement factor } \mathrm{H} \text { isoform } \\
\text { b precursor }\end{array}$ & 62739188 & 12 & 10 & 64 & 51 & 125 & 80 \\
\hline Complement factor H-related 1 & 118442839 & 2 & 0 & 4 & & only NC & 0 \\
\hline Complement factor I & 119392081 & 5 & 4 & 12 & 9 & 133 & 75 \\
\hline $\begin{array}{l}\text { Corticosteroid binding globulin } \\
\text { precursor }\end{array}$ & 73858564 & 2 & 0 & 6 & 1 & 600 & 17 \\
\hline Fibulin 1 isoform A precursor & 34734068 & 2 & 0 & 6 & & only NC & 0 \\
\hline Fibulin 1 isoform $\mathrm{C}$ precursor & 34734062 & 2 & 0 & 5 & & only NC & 0 \\
\hline Fibulin 1 isoform D & 34734066 & 2 & 0 & 2 & & only NC & 0 \\
\hline Haptoglobin-related protein & 45580723 & 2 & 0 & 2 & & only NC & 0 \\
\hline Heparin cofactor II precursor & 73858566 & 3 & 2 & 11 & 9 & 122 & 82 \\
\hline Plasma kallikrein B1 precursor & 78191798 & 2 & 2 & 6 & 3 & 200 & 50 \\
\hline plasminogen & 4505881 & 20 & 15 & 105 & 53 & 198 & 50 \\
\hline $\begin{array}{l}\text { Pregnancy specific } \\
\text { beta-1-glycoprotein } 1\end{array}$ & 21361392 & 4 & 5 & 17 & 8 & 213 & 47 \\
\hline $\begin{array}{l}\text { Pregnancy specific } \\
\text { beta-1-glycoprotein } 2\end{array}$ & 156616282 & 3 & 0 & 9 & & only NC & 0 \\
\hline $\begin{array}{l}\text { Pregnancy specific } \\
\text { beta-1-glycoprotein } 7 \text { precursor }\end{array}$ & 157805480 & 3 & 3 & 16 & 5 & 320 & 31 \\
\hline $\begin{array}{l}\text { Pregnancy-associated plasma } \\
\text { protein A preproprotein }\end{array}$ & 38045915 & 3 & 5 & 9 & 6 & 150 & 67 \\
\hline $\begin{array}{l}\text { Retinol-binding protein } 4 \text {, } \\
\text { plasma precursor }\end{array}$ & 55743122 & 3 & 0 & 4 & 1 & 400 & 25 \\
\hline $\begin{array}{l}\text { Serine (or cysteine) proteinase } \\
\text { inhibitor, clade } \mathrm{F} \text { (alpha-2 antiplasmin, } \\
\text { pigment epithelium derived factor), } \\
\text { member } 1\end{array}$ & 39725934 & 4 & 2 & 7 & 4 & 175 & 57 \\
\hline Serum amyloid A4, constitutive & 10835095 & 5 & 3 & 5 & 4 & 125 & 80 \\
\hline Sex hormone-binding globulin & 7382460 & 9 & 7 & 39 & 27 & 144 & 69 \\
\hline Transferrin & 4557871 & 21 & 2 & 56 & 4 & 1,400 & 7 \\
\hline
\end{tabular}

${ }^{\mathrm{a}} \mathrm{NCBI}$ database accession number, ${ }^{b} \mathrm{Negative}$ control group, ${ }^{\mathrm{C}}$ Preeclampsia group. 
A

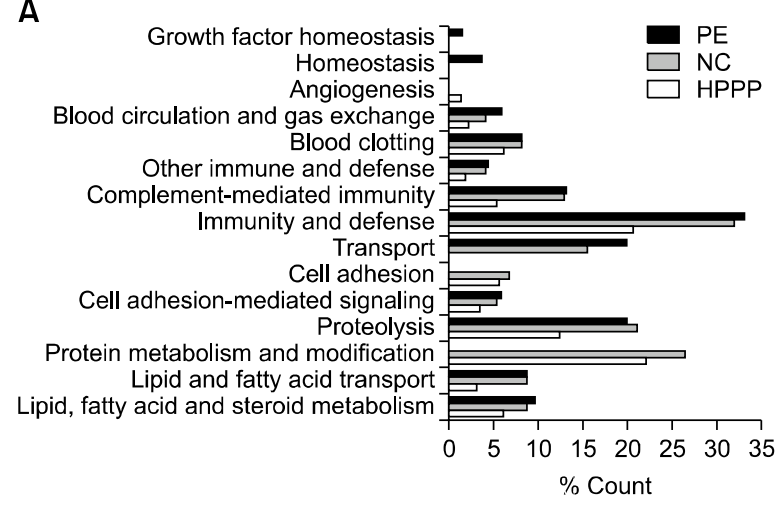

B

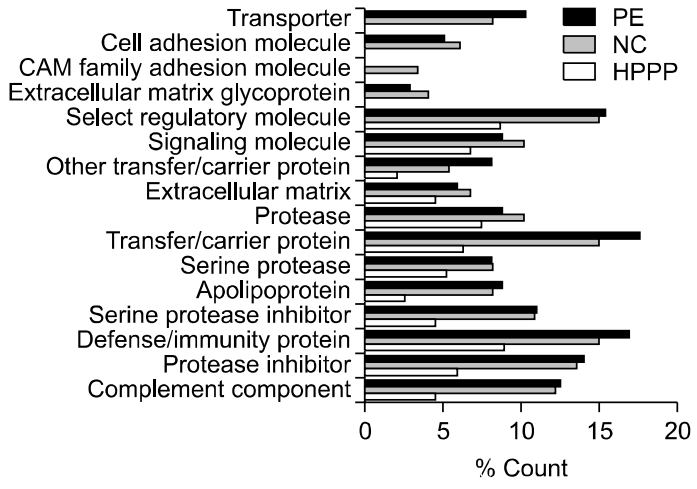

Figure 2. Gene functional clustering as determined by the Panther functional annotation tool; We compared identified serum proteins from both groups with 889 high confidence HUPO plasma proteome project (HPPP) proteins by gene functional clustering at $95 \%$ confidence. Gene functional clustering showed that biological processes associated with transport, growth factor homeostasis, cell adhesion and protein metabolism/modification were altered significantly when compared to the HPPP proteins (A). In the case of molecular functions (B), cell adhesion related proteins were changed in Preeclampsia.

biomarkers specific for each group, the relative expression levels of the identified proteins were compared by a semi-quantitative analysis based on spectral counting (Choi et al., 2008; Little et al., 2010). Eventually, 62 proteins showed more than 1.2 fold differences in expression levels, 27 of which were up regulated and 35 of which were down regulated according to their spectral counts (Table 3).

Those proteins identified from the profiling procedure with $1 \%$ FDR were further annotated based on their molecular function and biological process according to the gene ontology (GO) terms when compared with the control serum proteome acquired from the HUPO plasma proteome project (Adamski et al., 2005; Omenn et al., 2005) using the panther functional annotation tool (Thomas et al., 2003).

PE specifically altered proteins were mainly enriched in gene ontology terms of biological pro-
Table 4. SRM transitions for target proteins to monitor the quantitative changes in the progression of preeclampsia

\begin{tabular}{llrr}
\hline $\begin{array}{c}\text { Protein } \\
\text { name }\end{array}$ & \multicolumn{1}{c}{ Sequence } & \multicolumn{2}{r}{$\begin{array}{r}\text { Precursor } \\
\text { lon }(\mathrm{m} / \mathrm{z})\end{array}$} \\
\hline lon $(\mathrm{m} / \mathrm{z})$ \\
\hline AHSG & TWVQPSVGAAAGPWPPCPGR & 1009.2 & 683.7 \\
IGFBP-ALS & LWLEGNPWDCGCPLK & 923.6 & 1132.9 \\
RBP4 & YWGVASFLQK & 600.6 & 849.9 \\
AMBP & AFIQLWAFDAVK & 750.3 & 836.9 \\
\hline
\end{tabular}

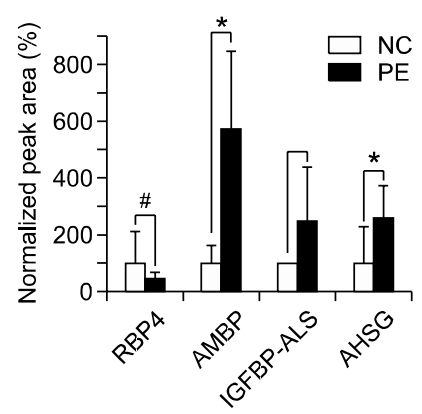

Figure 3. LC-SRM analysis of four candidate proteins, RBP4, AMBP IGFBP-ALS and AHSG; We analyzed serum samples of patients with PE and normal pregnancy. After monitoring of the selected peptides, we calculated relative peak areas of transitions for the target proteins. The protein levels of AMBP, IGFBP-ALS and AHSG were increased in PE patients ( ${ }^{*} P$-value $<0.05$ ), while those of RBP4 were decreased in PE patients $\left({ }^{\#} P\right.$-value $\left.=0.08\right)$.

cesses of protein metabolism/modification and cell adhesion were mainly enriched in the normal pregnancy group (Figure 2). For the selection of SRM target proteins, we chose target proteins for SRM analysis according to the criteria as follows: i) the target proteins should be differentially altered the expression levels compared with normal group. ii) Their pathophysiological functions should be related to the pathology of $P E$ based on previous reports. iii) Peptides of target proteins should have high SRM signal peaks in SRM scan mode, which guarantees a good analytical reproducibility with high probability.

According to these criteria, we selected four candidates as target proteins for further SRM ; alpha2-HS glycoprotein (AHSG), insulin like growth factor binding protein, acid labile subunit (IGFBPALS), retinol binding protein4 (RBP4) and alpha-1microglobulin/bikunin (AMBP). These target proteins then were validated by SRM runs with well- established transitions (peptide sequences, precursor ions and product ions) (Table 4).

For protein quantification, the peak areas of the individual SRM transitions were compared. Consequently, we could determine the relative expression levels of target proteins between the $P E$ group $(n=8)$ and normal group $(n=5)$. As shown in 


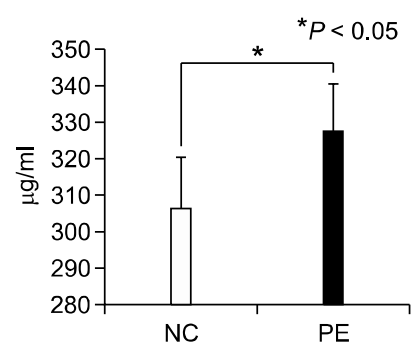

Figure 4. The results of human AHSG ELISA; Serum AHSG levels of normal control (NC, hatched bar) and preeclampsia (PE, dotted bar) were determined by human AHSG ELISA as described in the method. AHSG levels were increased in the PE group when compared with NC group. Statistical significance was determined using a Student's $t$-test * $P$ $<0.05$.

Figure 3, the expression levels of IGFBP-ALS, AMBP and AHSG were higher in serum samples collected from the PE group. The expression level of RBP4 in the PE group was reduced when compared to the normal group.

In previous studies, AHSG, which is synthesized in the liver and secreted into the blood stream, has been shown to be related to angiogenesis and insulin resistance. It has also been shown that serum AHSG levels are increased in patients with obesity or diabetes (Danzer et al., 1980; Thomas et al., 2003). This is an important indicator that AHSG is involved in the insulin signaling pathway. Furthermore, it appears to boost the likelihood of developing gestational diabetes during pregnancy (Srinivas et al., 1993; Kalabay et al., 2002; Swallow et al., 2004; Stefan et al., 2006; Briana et al., 2008). In fact, our results show that serum AHSG levels were increased in the PE group as determined by both the SRM assay (Figure 3) and ELISA assay (Figure 4).

A significant increase in AHSG was observed in serum samples with PE using a SRM assay (2.5 fold, $P<0.05)$. In contrast, the serum level of RBP4 was reduced by 2.4 fold in the PE group. Accordingly, a serum AHSG- ELISA assay showed a $10 \%$ increase of AHSG in the PE group $(P<$ 0.05).

\section{Discussion}

Recent achievements in proteomics have opened a new chapter in protein biomarker discovery, making a contribution to diagnosis in clinical practice. However, novel marker proteins are still rarely used clinically due to their limited reproducibility and specificity.

In this study, we developed an analytic technique using mass spectrometer based SRM for the quantification of biomarker proteins in the serum of pregnant women with severe PE. The results suggest that the mass spectrometry based quantification may be useful for the identification and quantification of differentially expressed proteins in clinical practice.

Although it has limitations, there is a need for a specific antibody against target proteins. However, it takes a long time to develop such assays; therefore, antibody-based immunoassays have been used as a powerful tool in the quantitative analysis of biological fluids. Furthermore, it is not possible to develop ELISA assays for all proteins in biological fluids in which the concentrations of proteins have an inherently large dynamic range and complexity. Therefore, mass spectrometry based assays have recently been introduced in this field (Aebersold and Mann, 2003).

In this study, we identified several proteins as potential diagnostic biomarkers for PE, IGFBPALS, AHSG and AMBP using proteomics technologies. In previous studies, some groups have reported that insulin like growth factors might be correlated with the pathophysiology of PE because of their abilities in fetal growth (Chard, 1994).

Ternary complex consisting of insulin like growth factor (IGF), insulin like growth factor binding protein (IGFBP) and IGFBP-ALS is believed to play a key regulatory role in the pathophysiology of $P E$ (Lewitt et al., 1995, 1998). One of these compounds, IGFBP-ALS, has been implicated in the stability of this complex and might regulate the supply of IGF in the blood stream and placenta. For these reasons, we speculated that IGFBP-ALS is important in the regulation of fetal and neonatal growth. Furthermore, our study showed that in PE pregnancy, serum levels of IGFBP-ALS were up-regulated by $50 \%$ when compared with normal pregnancies as determined by an SRM assay (Figure 4). Elevated levels of IGFBP-ALS might interact with IGF in the blood stream and interrupt the pathway to the placenta from blood. RBP4, one marker protein candidate for $\mathrm{PE}$, is generally known to be a carrier protein for retinol in blood (Rask et al., 1987). Moreover, in impaired insulin regulation, obesity or type 2 diabetes, RBP4 levels are up regulated in serum (Yang et al., 2005), which is an important contribution to insulin resistance. These findings suggest that there are pathological differences between impaired insulin regulation caused by diabetes and PE. Temporarily increased insulin resistance in normal pregnancy is likely due to an imbalance between enhanced maternal adiposity and insulin desensitizing by the placenta. In addition, other studies have found lower RBP4 levels in gestational diabetes (Graham et al., 2006). 
Therefore, these candidates are correlated with fetal growth and pathophysiology of PE, even though they will not all be accepted as new marker proteins due to the limited numbers of patients and normal. Accordingly, further studies are needed to investigate the differential expression of candidate marker proteins through systematic analysis of large numbers of patients for their clinical application.

Additionally, the causes of this disease and how to cure PE without pre-mature delivery are still not certain. Accordingly, it will eventually be necessary to investigate the pathogenesis and diagnosis of this disease to prevent fetal and maternal death. From this aspect, the Mass Spectrometer based SRM described herein will be useful in the discovery of biomarker proteins.

\section{Methods}

\section{Materials}

A multiple affinity removal system (MARS) column was purchased from Agilent Technologies (Santa Clara, CA). Sequencing grade modified trypsin was obtained from Promega (Madison, WI). Acetonitrile (HPLC grade), water (HPLC grade) and formic acid (ACS regent grade) were purchased from Aldrich (Milwaukee, WI). BCA protein assay reagent was acquired from PIERCE (Rockford, IL). A human Fetuin-A ELISA kit (BioVendor, Heidelberg, Germany) was used to determine the serum AHSG concentration.

\section{Study population and sample preparation}

We recruited eight pregnant women with severe PE and five with uncomplicated pregnancies. Five pregnant women from each group were targeted for the profiling of global serum proteins and all of the women were used for the quantitative analysis, SRM and ELISA for validation. The phenotype of the study population is presented in Table 1. We selected women who underwent elective cesarean delivery to eliminate labor effects on gene expressions. Prior to delivery, $10 \mu \mathrm{l}$ of venous blood was sampled from the forearm and collected into a vacutainer tube. Severe preeclampsia was defined as a blood pressure (BP) of at least $160 \mathrm{mmHg}$ (systolic) and/or $110 \mathrm{mmHg}$ (diastolic), with proteinuria $\geq 2+$ as determined via a dipstick test, measured on at least two occasions six hours apart after the $20^{\text {th }}$ week of gestation. Women with pre-existing chronic hypertension, renal disease, lupus erythematosus, diabetes, and gestational hypertension without proteinuria were excluded. This study was approved by the Institutional Review Board at Gangnam CHA Medical Center, College of Medicine, CHA University, and written informed consent was obtained from each patient.

\section{Depletion of abundant serum proteins}

To reduce the complexity of the serum protein, we removed the six most abundant proteins from the serum samples by MARS (Agilent Technologies, Santa Clara, CA) according to the manufacturer's instructions. This resulted in the depletion of albumin, transferrin, IgF, IgA, anti-trypsin, and haptoglobin from the human serum. The depleted serum samples were then desalted using a PepClean C18 spin column (thermo, Rockford, IL) to change the buffer (50 $\mathrm{mM} \mathrm{NH} \mathrm{NHCO}_{3}$ ), after which they were subject to in-solution tryptic digestion as follows: $10 \mu \mathrm{g}$ of depleted serum samples and $10 \mathrm{mM}$ of dithiothreitol were combined and incubated for $45 \mathrm{~min}$ at $60^{\circ} \mathrm{C}$ for protein reduction. Next, $5 \mathrm{mM}$ iodoacetamide was added and the samples were incubated for $30 \mathrm{~min}$ in the dark at room temperature to induce alkylation. The prepared mixture was then subjected to digestion with $125 \mathrm{ng}$ of trypsin for at least $4 \mathrm{~h}$ at $37^{\circ} \mathrm{C}$, after which the digested samples were lyophilized using a Speed-Vac and then re-suspended in $10 \mu \mathrm{l}$ of $0.1 \%$ TFA in HPLC water followed by desalting with a ZipTip C-18 column (Millipore Co., Billerica, MA) to remove the detergent and salt from the peptide mixture.

\section{Identification of serum proteins by LC-MS/MS}

The tryptic peptides were loaded onto a fused silica microcapillary column $(15 \times 75 \mu \mathrm{m})$ packed with $\mathrm{C} 18(5 \mu \mathrm{m}$, $200 \AA$ ) reversed phase resin and separated by LC using a linear gradient of $3-40 \%$ buffer $B$ for 50 min followed by $40-85 \%$ buffer B over 10 min (buffer A: $0.1 \%$ formic acid in $\mathrm{H}_{2} \mathrm{O}$, buffer $\mathrm{B}: 0.1 \%$ formic acid in acetonitrile) at a flow rate of $200 \mathrm{nl} / \mathrm{min}$. The column was connected directly to a LTQ ion-trap mass spectrometer (Finnigan, CA) equipped with a nano-electrospary ion source. The electrospray voltage was then set at $2.1 \mathrm{kV}$, and the threshold for switching from MS to MS/MS was 250 . The normalized collision energy for MS/MS was $35 \%$ of the main RF amplitude and the duration of activation was $30 \mathrm{~ms}$. All spectra were acquired in data-dependent mode. Each full MS scan was followed by five MS/MS scans corresponding to the most intense peak to the fifth most intense peak observed on the full MS scan. The repeat count of the peak for dynamic exclusion was 1 , and its repeat duration was $30 \mathrm{~s}$. The dynamic exclusion duration was set for $180 \mathrm{~s}$ and the exclusion mass width was $\pm 1.5 \mathrm{Da}$. The list size of the dynamic exclusion was $50 \mathrm{~s}$. The acquired MS/MS data was searched using the SEQUEST database search algorithm (Thermo Fisher Scientific Inc., MA) against the human NCBInr database (April 3, 2009 version) using a forward (target) a nd reverse (decoy) sequence. A decoy database was created with BioworksBrowser rev.3.3. Search parameters were as follows; specific to trypsin with two missed cleavage; $\pm 2.0 \mathrm{Da}$ precursor-ion tolerance; and \pm 1 Da fragment-ion tolerance; and fixed modifications, oxidation of Met (16 Da), alkylation of Cysteine (57 $\mathrm{Da})$. For a more-reliable protein list, the identified peptides were filtered to $1 \%$ FDR with the target-decoy database strategy (Elias and Gygi, 2007). 


\section{Selective reaction monitoring (SRM) assay}

In this study, a quantitative SRM assay was conducted to determine the relative concentration of proteins that were selected from the differentially expressed proteins by comparing PE samples to normal samples. Serum samples for the SRM assay were not subjected to depletion with the MARS column to avoid systematic errors associated with the sample preparation. We also monitored a set of SRM transitions of representative peptides corresponding to the differentially expressed proteins that were selected by comparing two groups by spectral counts and $\mathrm{GO}$ analysis. SRM mode was conducted by using a series of several scan events, with SRM being executed in each scan event. For SRM analysis of the target protein, the $\mathrm{m} / \mathrm{z}$ of $a$ precursor ion, which corresponds to a peptide of protein interest, was selected and the selected precursor ion was then fragmented by collision induced dissociation (CID). Among the resulting MS/MS peaks from the precursor ion, a representative peak was selected for the identification and/or quantification of the corresponding protein. The SRM transitions selected for monitoring potential candidate proteins were as follows: (1009.2 $\rightarrow 683.7$ for AHSG, TVVQPSVGAAAGPVVPPC\#PGR, C\# indicates caboxamidomethylation of Cysteine), (923.6 $\rightarrow 1132.9$ for IGFBPALS, LWLEGNPWDC\#GC\#PLK), (600.6 $\rightarrow 849.9$ for RBP4, YWGVASFLQK), (750.3 $\rightarrow 836.9$ for AMBP, AFIQLWAFDAVK) and $(758.0 \rightarrow 1160.0$ for internal standard peptide for normalization, DHTGFLTEYVATR). The number of total scan events was six, and these consisted of one full MS scan event and five subsequent SRM scans. On the CID condition, the normalized collision energy was $35 \%$ of the main RF amplitude and the duration of activation was 30 $\mathrm{ms}$. The peak width of the precursor and MS/MS daughter ion for SRM were \pm 1 and $\pm 2.5 \mathrm{Da}$, respectively.

\section{ELISA assay}

Equal amounts of sera were analyzed using a human AHSG ELISA kit (BioVendor, Heidelberg, Germany). Sandwich ELISA was conducted according to the manufacturer's instructions. Next, $100 \mu \mathrm{l}$ of diluted standards were added to each well of the quality control and samples and the plate was incubated on an orbital microplate shaker under room temperature for $1 \mathrm{~h}$. After washing the well three times, $100 \mu \mathrm{l}$ of conjugate solution was added and the plate was then incubated for $1 \mathrm{~h}$ at room temperature while shaking at $300 \mathrm{rpm}$. The plate was washed then washed three times with wash solution, after which $100 \mu \mathrm{l}$ of substrate solution was added into each well and the plate was incubated for around 10 minutes to enable the reaction to develop. Finally, the absorbance at $450 \mathrm{~nm}$ was measured using an ELISA plate reader.

\section{Statistical analysis}

The statistical significance of the measurements was compared using a student's $t$-test via MedCalc program (MedCalc software, Mariakerke, Belgium, version 11.3.3.0).

\section{Acknowledgements}

This work was supported by grants from Konkuk University and Korea Health 21 R\&D Project (No. A080611) of Ministry of Health and Welfare, Republic of Korea.

\section{References}

Adamski M, Blackwell T, Menon R, Martens L, Hermjakob H, Taylor C, Omenn GS, States DJ. Data management and preliminary data analysis in the pilot phase of the HUPO Plasma Proteome Project. Proteomics 2005;5:3246-61

Aebersold R, Mann M. Mass spectrometry-based proteomics. Nature 2003;422:198-207

Audibert F, Benchimol Y, Benattar C, Champagne C, Frydman $\mathrm{R}$. Prediction of preeclampsia or intrauterine growth restriction by second trimester serum screening and uterine Doppler velocimetry. Fetal Diagn Ther 2005;20: 48-53

Ballif BA, Roux PP, Gerber SA, MacKeigan JP, Blenis J, Gygi SP. Quantitative phosphorylation profiling of the ERK /p90 ribosomal S6 kinase-signaling cassette and its targets, the tuberous sclerosis tumor suppressors. Proc Natl Acad Sci USA 2005;102:667-72

Baumann MU, Bersinger NA, Surbek DV. Serum markers for predicting pre-eclampsia. Mol Aspects Med 2007;28:227-44

Bersinger NA, Odegard RA. Second- and third-trimester serum levels of placental proteins in preeclampsia and small-for-gestational age pregnancies. Acta Obstet Gynecol Scand 2004;83:37-45

Borzychowski AM, Sargent IL, Redman CW. Inflammation and pre-eclampsia. Semin Fetal Neonatal Med 2006;11: 309-16

Briana DD, Boutsikou M, Gourgiotis D, Boutsikou T, Baka S, Marmarinos A, Hassiakos D, Malamitsi-Puchner A. Serum fetuin-A/alpha2-HS-glycoprotein in human pregnancies with normal and restricted fetal growth. J Matern Fetal Neonatal Med 2008;21:826-30

Chard T. Insulin-like growth factors and their binding proteins in normal and abnormal human fetal growth. Growth Regul 1994;4:91-100

Choi H, Fermin D, Nesvizhskii Al. Significance analysis of spectral count data in label-free shotgun proteomics. Mol Cell Proteomics 2008;7:2373-85

Danzer H, Braustein GD, Rasor J, Forsythe A, Wade ME. Maternal serum human chorionic gonadotropin concentrations and fetal sex prediction. Fertil Steril 1980;34:336-40

Elias JE, Gygi SP. Target-decoy search strategy for increased confidence in large-scale protein identifications by mass spectrometry. Nat Methods 2007;4:207-14

Graham TE, Yang Q, Bluher M, Hammarstedt A, Ciaraldi TP, Henry RR, Wason CJ, Oberbach A, Jansson PA, Smith U, Kahn BB. Retinol-binding protein 4 and insulin resistance in lean, obese, and diabetic subjects. N Engl J Med 2006; 354:2552-63 
Hu S, Loo JA, Wong DT. Human body fluid proteome analysis. Proteomics 2006;6:6326-53

Jauniaux E, Poston L, Burton GJ. Placental-related diseases of pregnancy: Involvement of oxidative stress and implications in human evolution. Hum Reprod Update 2006;12: 747-55

Ji QC, Rodila R, Gage EM, El-Shourbagy TA. A strategy of plasma protein quantitation by selective reaction monitoring of an intact protein. Analytical chemistry 2003;75:7008-14

Kalabay L, Cseh K, Pajor A, Baranyi E, Csakany GM, Melczer Z, Speer G, Kovacs M, Siller G, Karadi I, Winkler G. Correlation of maternal serum fetuin/alpha2-HS-glycoprotein concentration with maternal insulin resistance and anthropometric parameters of neonates in normal pregnancy and gestational diabetes. Eur J Endocrinol 2002; $147: 243-8$

Lewitt MS, Scott FP, Clarke NM, Baxter RC. Developmental regulation of circulating insulin-like growth factor-binding proteins in normal pregnancies and in pre- eclampsia. Prog Growth Factor Res 1995;6:475-80

Lewitt MS, Scott FP, Clarke NM, Wu T, Sinosich MJ, Baxter $\mathrm{RC}$. Regulation of insulin-like growth factor-binding protein-3 ternary complex formation in pregnancy. J Endocrinol 1998; 159:265-74

Little KM, Lee JK, Ley K. ReSASC: a resampling-based algorithm to determine differential protein expression from spectral count data. Proteomics 2010;10:1212-22

Muller F, Savey L, Le Fiblec B, Bussieres L, Ndayizamba G, Colau JC, Giraudet P. Maternal serum human chorionic gonadotropin level at fifteen weeks is a predictor for preeclampsia. Am J Obstet Gynecol 1996;175:37-40

Noris M, Perico N, Remuzzi G. Mechanisms of disease: Pre-eclampsia. Nat Clin Pract Nephrol 2005;1:98-114; quiz 120

Omenn GS, States DJ, Adamski M, Blackwell TW, Menon R, Hermjakob H, Apweiler R, Haab BB, Simpson RJ, Eddes JS, Kapp EA, Moritz RL, Chan DW, Rai AJ, Admon A, Aebersold R, Eng J, Hancock WS, Hefta SA, Meyer H, Paik YK, Yoo JS, Ping P, Pounds J, Adkins J, Qian X, Wang R, Wasinger V, Wu CY, Zhao X, Zeng R, Archakov A, Tsugita A, Beer I, Pandey A, Pisano M, Andrews P, Tammen H, Speicher DW, Hanash SM. Overview of the HUPO Plasma Proteome Project: results from the pilot phase with 35 collaborating laboratories and multiple analytical groups, generating a core dataset of 3020 proteins and a publicly-available database. Proteomics 2005;5:3226-45

Rask L, Anundi H, Fohlman J, Peterson PA. The complete amino acid sequence of human serum retinol-binding protein. Ups J Med Sci 1987;92:115-46

Ryu J, Lee SR, Park SG, Kang S, Kim HJ, Park BC. Change in serum proteome during allogeneic hematopoietic stem cell transplantation and clinical significance of serum C-reactive protein and haptoglobin. Exp Mol Med 2010;42:651-61

Smets EM, Visser A, Go AT, van Vugt JM, Oudejans CB. Novel biomarkers in preeclampsia. Clin Chim Acta 2006; 364:22-32

Spencer K, Cowans NJ, Nicolaides KH. Low levels of maternal serum PAPP-A in the first trimester and the risk of pre-eclampsia. Prenat Diagn 2008;28:7-10

Srinivas PR, Wagner AS, Reddy LV, Deutsch DD, Leon MA, Goustin AS, Grunberger G. Serum alpha 2-HS- glycoprotein is an inhibitor of the human insulin receptor at the tyrosine kinase level. Mol Endocrinol 1993;7:1445-55

Stefan N, Hennige AM, Staiger H, Machann J, Schick F, Krober SM, Machicao F, Fritsche A, Haring HU. Alpha2Heremans-Schmid glycoprotein/fetuin-A is associated with insulin resistance and fat accumulation in the liver in humans. Diabetes Care 2006;29:853-7

Swallow CJ, Partridge EA, Macmillan JC, Tajirian T, DiGuglielmo GM, Hay K, Szweras M, Jahnen-Dechent W, Wrana JL, Redston M, Gallinger S, Dennis JW. alpha2HSglycoprotein, an antagonist of transforming growth factor beta in vivo, inhibits intestinal tumor progression. Cancer Res 2004;64:6402-9

Taylor RN. Review: immunobiology of preeclampsia. Am J Reprod Immunol 1997;37:79-86

Teixeira PG, Cabral AC, Andrade SP, Reis ZS, da Cruz LP, Pereira JB, Martins BO, Rezende CA. Placental growth factor (PIGF) is a surrogate marker in preeclamptic hypertension. Hypertens Pregnancy 2008;27:65-73

Thomas PD, Campbell MJ, Kejariwal A, Mi H, Karlak B, Daverman R, Diemer K, Muruganujan A, Narechania A. PANTHER: a library of protein families and subfamilies indexed by function. Genome Res 2003;13:2129-41

Venkatesha S, Toporsian M, Lam C, Hanai J, Mammoto T, Kim YM, Bdolah Y, Lim KH, Yuan HT, Libermann TA, Stillman IE, Roberts D, D'Amore PA, Epstein FH, Sellke FW, Romero $R$, Sukhatme VP, Letarte M, Karumanchi SA. Soluble endoglin contributes to the pathogenesis of preeclampsia. Nat Med 2006;12:642-9

Whiteaker JR, Zhang $\mathrm{H}$, Eng JK, Fang R, Piening BD, Feng LC, Lorentzen TD, Schoenherr RM, Keane JF, Holzman T, Fitzgibbon M, Lin C, Cooke K, Liu T, Camp DG 2nd, Anderson L, Watts J, Smith RD, Mclntosh MW, Paulovich AG. Head-to-head comparison of serum fractionation techniques. J Proteome Res 2007;6:828-36

Yang Q, Graham TE, Mody N, Preitner F, Peroni OD, Zabolotny JM, Kotani K, Quadro L, Kahn BB. Serum retinol binding protein 4 contributes to insulin resistance in obesity and type 2 diabetes. Nature 2005;436:356-62 